\title{
Effects of Hormones on Postimplantation Mouse Embryos In Vitro. II. Progesterone and Estrogen
}

\author{
D.L. FISHER AND L. MARTINEZ DE VILLARREAL \\ Department of Anatomy and Cell Biology, The University of Michigan, Ann \\ Arbor, Michigan 48109 (D.L.F.), and Departamento de Embriologia, \\ Facultad de Medicina, Universidad Autónoma de Nuevó Leon, Monterrey, \\ N.L. México (L.M.V.)
}

\begin{abstract}
Mouse embryos at day 9 of development were cultured for 24 to $42 \mathrm{~h}$ in $50 \%$ fetal calf serum and $50 \%$ Waymouth's medium containing $0.5 \mu \mathrm{g} / \mathrm{ml}$ insulin supplemented with various amounts of progesterone and estradiol-17- $\beta$. Unmodified medium contained approximately $0.2 \%$ of the normal maternal blood levels for that stage of pregnancy. The addition of $1 \times 10^{-7} \mathrm{M}$ progesterone to the medium brought the level near that of the normal maternal circulating amount and appeared to be beneficial for in vitro development. After $24 \mathrm{~h}$ of cultivation there was a statistically significant increase in somite number, the number of embryos developing posterior limb buds, and protein accumulation over the control embryos. The addition of small amounts of estradiol-17 $\beta$ ( $1 \times$ $10^{-10} \mathrm{M}$ ) increased the protein accumulation of the embryo over that of progesterone alone and seems to enhance the beneficial effects of progesterone addition.
\end{abstract}

Shortly after implantation, the embryo is exposed to increasing amounts of progesterone and estrogen produced by the developing placenta. It has been suggested that almost half of these steroids pass to the developing fetus (review by Solomon and Friesen, '68). It seems reasonable that the developing fetus must utilize or inactivate these physiologically active substances or suffer irreversible dam. age (review by Levitz, '66).

Progesterone and estrogen appear to regulate cell metabolism and catabolism, as well as influence the synthesis of proteins in target tissues (O'Malley and Means, '74). The steroids may also modulate the role of transcription of certain genes in the nucleus of target cells (Jensen and DeSombre, '72).

Toward the latter half of pregnancy approximately $40 \%$ of the progesterone is either sulfated or converted to estrogen precursors to be used by the mother for increased estrogen production (Harbert et al., '64). Very little is known, however, about the utilization of progesterone by the embryo in the early half of pregnancy, especially before the fetal suprarenal glands and liver are functioning (review by Diczfalusy, '67). The present study was designed to monitor the effects of altered progesterone and estrogen concentrations on the early developing mouse embryo.

\section{MATERIALS AND METHODS Embryo collection and cultivation}

Virgin female mice, strain $129 \mathrm{SvSl}$, were housed, five females per male, and given water and a commercial mouse diet ad libitum. A 15$\mathrm{hr}$ light cycle was used. The day of finding the copulation plug was designated day 0 of pregnancy. The same methods for obtaining and culturing in vitro embryos reported earlier were used (Fisher, '80). The 9-day embryos collected were dissected according to the method of New and Coppola ('77). Eleven-day embryos were dissected according to the method of Cockroft ('73). The 9-day embryos were at the 10-14 somite stage and were beginning to rotate from a dorsiflexed to a ventroflexed position. The neural tube was not yet closed and limb buds were absent. The visceral yolk sac circulation was not evident. The 11-day embryos were ventroflexed, had a vigorous visceral yolk sac circulation, prominent anterior, and posterior limb buds were evident and the eye ring was about one-half completed.

\footnotetext{
Address reprint requests to D.L. Fisher, 4608 Med. Sci. II Department of Anatomy and Cell Biology, The University of Michigan, Ann Arbor, MI 48109.
} 
The cultivation method followed that described by Kochhar ('75) using $50 \%$ fetal calf serum (GIBCO, Grand Island, NY) and 50\% Waymouth's medium (GIBCO). The Waymouth's medium was supplemented with $0.5 \%$ $\mu \mathrm{g} / \mathrm{ml}$ sodium insulin, 5,000 U/liter penicillin, $5,000 \mu \mathrm{g}$ /iter streptomycin, and $4 \mathrm{gm} /$ liter bovine serum albumin (Sigma). Progesterone (dissolved in 100\% alcohol) was added to the culture medium to yield final concentrations of $1 \times 10^{-5}, 10^{-6}$, and $10^{-7}, 10^{-8} \mathrm{M}$. Estrogen as estradiol-17 $\beta$ (dissolved in $100 \%$ alcohol) was added to yield a final concentration in the cultivation medium of $1 \times 10^{-8}, 10^{-11}$, and $10^{-12}$. The amount of alcohol added was kept constant at $0.5 \mu \mathrm{l} / \mathrm{ml}$ medium. Control embryos were cultured in the absence of progesterone or estrogen with and without alcohol. Data were pooled for control embryos since no significant morphological or biochemical differences were noted after the addition of small amounts of alcohol.

Embryos were placed singly in 10-ml screwcap plastic test tubes containing $1.5 \mathrm{ml}$ of medium maintained at $37^{\circ} \mathrm{C}$ and rotated on a mechanical rotator at $30-40 \mathrm{rpm}$. The gassing sequence used was that suggested by New and Coppola ('77) beginning with $10 \% \mathrm{O}_{2}, 5 \%$ $\mathrm{CO}_{2}$, and $85 \%$ nitrogen. The $\mathrm{O}_{2} \%$ was increased every $12-15 \mathrm{~h}$ to $20 \%, 50 \%$, and $80 \%$. Nitrogen was decreased concomitantly. The $5 \% \mathrm{CO}_{2}$ was held constant for stabilization of $\mathrm{pH}$. The embryos were transferred to fresh medium after $24 \mathrm{~h}$ if cultivation was continued. Termination was at $42 \mathrm{~h}$.

On the 9-day embryos at least five separate repetitive experiments were made for each dose of progesterone and estrogen used. No less than 25 total embryos were used for each dose. A total of 479 embryos from 78 dams was used for the determinations. A total of 261 11-day embryos was used for protein determinations.

Progesterone and estrogen levels were determined by radioimmunoassay in all media and blood serum used. Progesterone levels were assayed according to the methods of Niswender ('73) and Foster et al. ('75, '78). Estrogen levels were assayed according to the method of England et al. ('74). Mouse serum samples were obtained by decapitation of nonpregnant females and at gestation days 9, 10, and 17.

\section{Analytic methods}

Developmental parameters were analyzed for each dosage level examined. Growth in size and shape was selectively tabulated by photographic measurements. Heart rate was timed by stopwatch for $15 \mathrm{sec}$ at $37^{\circ} \mathrm{C}$. Somite numbers were counted. Subjective comparisons of treated and nontreated embryos were made for closure of the anterior and posterior neuropores; rotation to a ventroflexed position; presence of anterior and posterior limb bud swellings; establishment of visceral yolk sac circulation; fusion of the amniotic and allantoic sacs; and presence or absence of an edematous condition in the pericardial sac or ventricles of the brain.

Protein was analyzed by the method of Lowry et al. ('51). At 0 and $24 \mathrm{~h}$, the homogenate of $4 / 5$ embryo was used for analysis. At $42 \mathrm{~h}$, the homogenate was diluted by one-half.

The DNA and RNA were analyzed by the ethidium bromide fluorometric technic of Prasad et al. ('72), as modified by Ritter ('78) to include the expected values of DNA and RNA for 9-day mouse embryos within the standard dilution curve. Spectrofluorometer excitation wavelength was $365 \mathrm{~nm}$ and emission wavelength was $590 \mathrm{~nm}$. Analysis was made on 1/5 embryo at 0,24 , and/or $42 \mathrm{~h}$ for each experiment.

A multiple linear regression analysis was used with $P$ values less than 0.05 indicating a level of significance. Student's t-test was used for comparison between treated and nontreated embryos. An analysis of variance and Dunnett's D statistic were also compared. The correlation coefficients of linearized standard curves were all greater than $r=0.991$.

\section{RESULTS \\ Biochemical analysis}

Radioimmunoassay of the fetal calf serum for progesterone showed a level of $5.8 \times$ $10^{-10} \mathrm{M}$, which was lower than that reported by Esber et al. ('73), at $2.6 \pm 1.1 \times 10^{-9} \mathrm{M}$, but higher than that reported by Milo et al. (76) at approximately $2.5 \pm 0.5 \times 10^{-10} \mathrm{M}$. The culture medium used before the addition of progesterone showed a level of $7.2 \pm 1.5 \times$ $10^{-10} \mathrm{M}$.

It is obvious that the progesterone content in fetal calf serum will differ in various samples. However, the concentration in all samples was considerably less than the normal circulating level of progesterone for pregnant females in this strain of mouse (Table 1). Although a rise is indicated, the progesterone levels at days 9,10 , and 17 are not significantly different from one another. The litter size from 
TABLE 1. Progesterone levels in strain $129 \mathrm{SvSl}$ at various stages of pregnancy

\begin{tabular}{lccc}
$\begin{array}{l}\text { Stage of } \\
\text { pregnancy }\end{array}$ & $\begin{array}{c}\text { Number of } \\
\text { samples }\end{array}$ & $\begin{array}{c}\text { Mean number of } \\
\text { embryos in litter }\end{array}$ & \begin{tabular}{c} 
Molar concentration \\
\hline Nonpregnant
\end{tabular} \\
Day 9 & 16 & $7.3 \pm 0.6$ & $3.7 \pm 0.4 \times 10^{-\times} \mathrm{M}$ \\
Day 10 & 11 & $7.2 \pm 0.7$ & $2.5 \pm 0.4 \times 10^{-7} \mathrm{M}$ \\
Day 17 & 9 & $6.0 \pm 0.8$ & $3.0 \pm 0.3 \times 10^{-7} \mathrm{M}$ \\
\hline
\end{tabular}

TABLE 2. Protein accumulation in 9-day mouse embryos exposed to various levels of progesterone

\begin{tabular}{|c|c|c|c|c|}
\hline \multirow{2}{*}{$\begin{array}{l}\text { Progesterone } \\
\text { addition to } \\
\text { Waymouth's } \\
\text { medium in M }\end{array}$} & \multirow{2}{*}{$\begin{array}{c}\text { Total } \\
\text { number } \\
\text { assayed }\end{array}$} & \multicolumn{3}{|c|}{$\begin{array}{l}\mu \mathrm{g} \text { protein/embryo } \\
\text { (hours of cultivation) }\end{array}$} \\
\hline & & 0 & 24 & 42 \\
\hline 0 & 72 & $52.1 \pm 8.3$ & $84.4 \pm 6.8$ & $121.1 \pm 18.3$ \\
\hline $1 \times 10^{-5}$ & 52 & $57.1 \pm 6.7$ & $90.8 \pm 10.1$ & $136.0 \pm 25.1$ \\
\hline $1 \times 10^{-6}$ & 83 & $63.0 \pm 5.6$ & $101.9 \pm 6^{*}$ & $146.3+14.4$ \\
\hline $\begin{array}{l}1 \times 10^{-7} \\
1 \times 10^{-7}+\end{array}$ & 91 & $67.5 \pm 7.1$ & $99.7 \pm 5.1^{*}$ & $133.6 \pm 12.8$ \\
\hline $\begin{array}{l}1 \times 10^{-10} \mathrm{M} \\
\text { Estradiol-17\% }\end{array}$ & 33 & $61.5 \pm 9.1$ & $106.9 \pm 8.8^{*}$ & $173.1 \pm 21.8^{*}$ \\
\hline $1 \times 10^{-8}$ & 51 & $69.7 \pm 14.4$ & $112.6 \pm 10.7^{*}$ & $161.3 \pm 25$ \\
\hline
\end{tabular}

*Significantly different from controls, $\mathrm{P}<0.05$.

TABLE 3. Protein accumulation in 11-day mouse embryos

\begin{tabular}{|c|c|c|c|}
\hline \multirow{2}{*}{$\begin{array}{c}\text { Exogenous } \\
\text { steroid exposure }\end{array}$} & \multirow{2}{*}{$\begin{array}{l}\text { Number of } \\
\text { embryos } \\
\text { assayed }\end{array}$} & \multicolumn{2}{|c|}{$\begin{array}{l}\text { Protein in } \mu \mathrm{g} / \mathrm{embryo} \\
\text { (hours exposed) }\end{array}$} \\
\hline & & 0 & 24 \\
\hline $1 \times 10^{-6} \mathrm{M}$ & 149 & $1463.0 \pm 62.1$ & $2403.7 \pm 81.8$ \\
\hline $\begin{array}{l}\text { progesterone } \\
\text { and } 1 \times 10^{-10} \mathrm{M} \\
\text { estrogen }\end{array}$ & 112 & $1399.0 \pm 56.3$ & $2341.1 \pm 64.9$ \\
\hline
\end{tabular}

pregnant females also did not differ significantly in any day sample.

The radioimmunoassay of fetal calf serum for estradiol-17 $\beta$ showed a level of $3.0 \pm 0.2$ $\times 10^{-10} \mathrm{M}$, which did not differ from that of Esber et al. ('73) but was different from one of the assays reported by Milo et al. ('76). The estradiol present in our culture medium after the addition of $1 \times 10^{-10} \mathrm{M}$ estradiol- $17 \beta$ was similar to that found in the serum of 9-day pregnant mice at $4.7 \pm 0.2 \times 10^{-10} \mathrm{M}$. The estradiol level for the nonpregnant adult female mice from pooled samples was $3.4 \pm 0.2$ $\times 10^{-10} \mathrm{M}$.

Protein accumulation values at the beginning of cultivation did not differ significantly between controls and experimentals. A significant increase in protein accumulation was noted for embryos exposed to $1 \times 10^{-6}, 10^{-7}$, and $10^{-8} \mathrm{M}$ progesterone after $24 \mathrm{~h}$ in culture. After $42 \mathrm{~h}$ these were no longer significantly different. The addition of $1 \times 10^{-10} \mathrm{M}$ estradiol $17-\beta$ to the medium for embryos exposed to 1 $\times 10^{-7} \mathrm{M}$ progesterone produced a significant increase in accumulation of protein/embryo after 24 and $42 \mathrm{~h}$ (Table 2).

The effects of progesterone and estrogen on protein accumulation after a vigorous yolk sac circulation develops was also determined on 11-day mouse embryos. We were unable to detect a statistically significant difference in protein accumulation levels due to the presence or absence of progesterone and estrogen additions to the medium (Table 3 ).

The accumulation of DNA was found to rise slightly at the lower doses of progesterone on 9-day embryos; however, the differences were not statistically significant. A similar finding 
was also evident with RNA accumulation. No differences in DNA or RNA were noted in treated or nontreated 11-day embryos.

\section{Gross morphologic changes}

Growth and differentiation of the 9-day embryo were also improved in some instances by exposure to additional progesterone. The most obvious changes were the increase in total somite numbers (Fig. 1) for the doses $1 \times 10^{-6}$, $10^{-7}$, and $10^{-8} \mathrm{M}$ and the appearance of posterior limb buds in those embryos exposed to the same dosages (Fig. 2). The addition of estrogen to the medium led to no further significant differences from the controls in terms of gross morphological changes. No significant morphological differences were noted in treated or nontreated 11-day embryos.

The number of somites at the beginning of cultivation of the 9-day embryos was similar for all groups. By $24 \mathrm{~h}$ the lower dosage levels of $1 \times 10^{-7} \mathrm{M}$ and $1 \times 10^{-8} \mathrm{M}$ progesterone exposure produced significant increases in number of somites over the control level, and by $42 \mathrm{hr}$ the $1 \times 10^{-6} \mathrm{M}$ progesterone level gave a similar result (Fig. 1).

The appearance of posterior limb bud swellings in the 9-day cultivated embryos was not noted at any time during culture for the control embryos but began appearing in a small percentage of the embryos by $24 \mathrm{~h}$ for $1 \times$

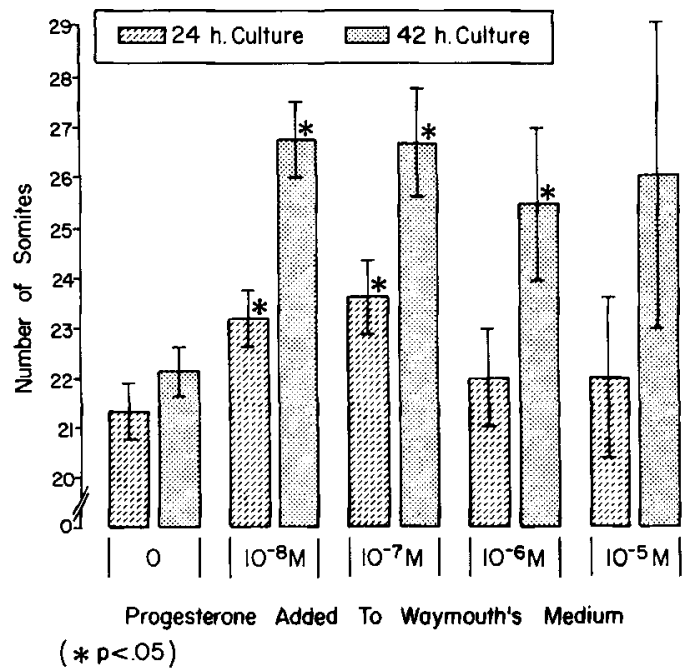

Fig. 1. Effect of progesterone addition to the culture medium on the growth as determined by total somite numbers. Each bar represents 25 or more embryos examined. Vertical lines represent SE. Ordinate broken to indicate values do not begin with zero.

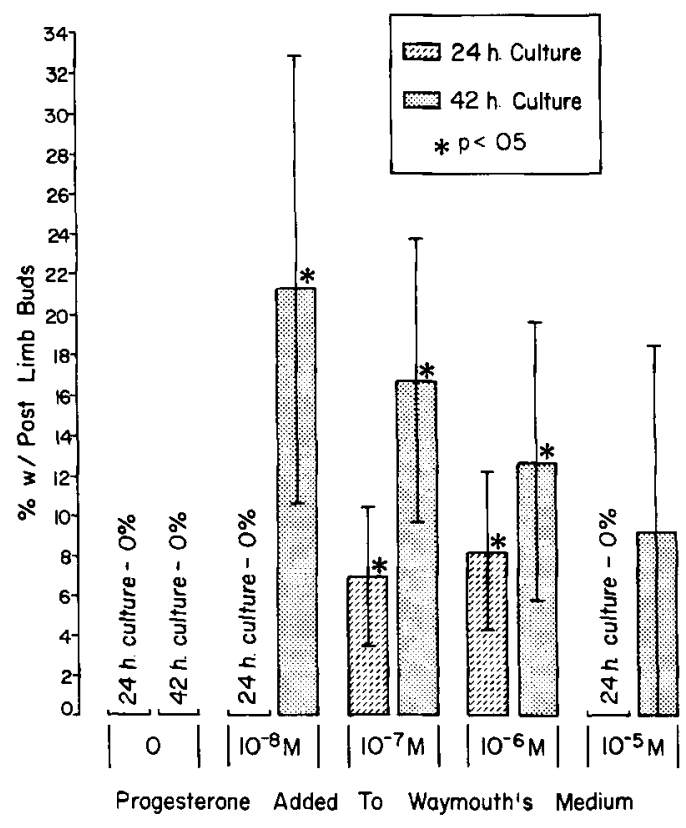

Fig. 2 Effect of progesterone addition to the culture medium on the appearance of posterior limb buds during the cultivation period. Each bar represents 25 or more embryos examined. Vertical lines represent SE.

$10^{-6} \mathrm{M}$ and $1 \times 10^{-7} \mathrm{M}$ exposure. By $42 \mathrm{~h}$ the appearance of posterior limb bud swellings was noted in $10-22 \%$ of the embryos for all doses of progesterone tested (Fig. 2).

Accumulation of fluid in the pericardial sac and ventricles of the brain was noted in the 9day cultivated embryos in a small percentage of the controls after 24 hours of cultivation $(15.4 \pm 5.1 \%$ and $11.7 \pm 4.2 \%$, respectively). Pericardial fluid accumulation was significantly increased by the higher doses of progesterone exposure to $61.4 \pm 7.4 \%$ and $36.7 \pm 8.9 \%$ for $1 \times 10^{-5} \mathrm{M}$ and $1 \times 10^{-6} \mathrm{M}$, respectively, but was not significantly altered by the $1 \times 10^{-7} \mathrm{M}$ or $1 \times 10^{-8} \mathrm{M}$ dosages. Brain ventricular fluid accumulation was significantly elevated in only the $1 \times 10^{-5} \mathrm{M}$ progesterone exposure.

Neither heart rate, closure of the anterior or posterior neuropores, rotation to a ventroflexed position, establishment of a visceral yolk sac circulation, fusion of the amniotic and allantoic sacs, nor the appearance of anterior limb buds for the 9-day cultivated embryos was affected by the addition of progesterone to the medium. The addition of estrogen did not alter these findings. Heart rate was not affected in the 11-day cultivated embryos. 


\section{DISCUSSION}

The results of this study indicate that the addition of progesterone and estrogen to the cultivation medium at or near the normal in vivo circulating levels can improve the morphological development and protein accumulation levels of mouse embryos in vitro between the ninth and tenth days of development. If, however, the 11-day mouse embryos are cultured for $24 \mathrm{~h}$, the observable changes are no longer evident.

Although nothing is known on early embryonic effects of progesterone, the idea that this hormone may play a role in fetal development is not new. Guerne and Stutinsky ('78) found no steroid receptors in the fetal portion of the placenta, but they felt that fetal growth may be regulated indirectly by hormonal stimuli as they were able to demonstrate increased growth response in rabbit embryos. Vito and Fox ('79) have also demonstrated that the em. bryonic rodent brain by day 17 has the biochemical potential to respond to its sex steroid environment. Diczfalusy ('67) found, by perfusion of the midterm human fetus with $50 \mu \mathrm{c}$ of ${ }^{14} \mathrm{C}$-labeled progesterone, that uptake of the label could be observed in a number of embryonic structures, including heart, liver, suprarenal, testicular, and neural tissues.

It is obvious that the fetal-placental unit once established is metabolically active as evidenced by hormonal production after implantation has occurred (Soloman and Friessen, '68). We noted that as progesterone, added to the medium, approaches the observed peak levels in the maternal circulation, protein accumulation as well as morphologic development in the early embryo was enhanced. The addition of estrogen, approaching in vivo levels, to medium containing progesterone, increased embryonic protein accumulation. Estrogen appears to act as a primer to enhance progesterone response. This has been reported by a number of investigators (review by Jensen and DeSombre, '72).

It is evident that $1 \times 10^{-8} \mathrm{M}$ progesterone addition, which is below circulating levels, was still beneficial to development compared to smaller amounts. It has also been reported, when using homologous serum for rat embryos in vitro, that serum from donors need not be correlated by stage of pregnancy or sex with lowered progesterone and estrogen levels (New '67). The use of human serum has yielded similar results (Chatot et al. '80). A minimal threshold level of this steroid may, therefore, be necessary to benefit the embryo for at least part of the embryonic developmental period. The addition of excessive progesterone is unnecessary, however, and may suggest that activities such as the observed catabolic effects of progesterone (Landau and Lugibihl, '61) may no longer be beneficial. The increase in pericardial and ventricular fluid for higher doses of progesterone in our experiments suggest the detrimental effects of excessive progesterone. It is recommended, therefore, that progesterone and estrogen addition at $1 \times 10^{-6} \mathrm{M}$ to $10^{-8} \mathrm{M}$ and $1 \times 10^{-10} \mathrm{M}$, respectively, which appears to enhance development of the embryo for a short time, be included as an integral part of a defined cultivation medium.

\section{ACKNOWLEDGMENTS}

Special thanks are given to Francine Hale for skilled technical assistance and to Dr. B. England's laboratory of the University of Michigan for assistance with the radioimmunoassay for progesterone and estrogen.

\section{LITERATURE CITED}

Chatot, C.L., N.W. Klein, J. Piatek, and L.J. Pierro (1980) Successful culture of rat embryos on human serum: Use in the detection of teratogens. Science, 207(4438):14711473.

Cockroft, D.L. (1973) Development of rat foetuses explanted at 12.5 and 13.5 days of gestation. J. Embryol. Exp. Morph., 29(2):473-483.

Diczfalusy, E. (1967) Endocrinology of the fetoplacental unit. In: Fetal Homeostasis. R.M. Wynn, ed. The New York Academy of Sciences, New York, Vol. 2, pp. 268361.

England, B.G., G.D. Niswender, and A.R. Midgley, Jr. (1974) Radioimmunoassay of estradiol-17 $\beta$ without chromatography. J. Clin. Endocrinol. Metab., 38:42.

Esber, H.J., J. Payne, and A.E. Bogden (1973) Variability of hormone concentrations and ratios in commercial sera used for tissue culture. J. Natl Cancer Inst., 50(2):559562.

Fisher, D.L. (1980) Effects of hormones on post-implantation mouse embryos in vitro. I. Insulin. J. Exp. Zool., 211:387-393.

Foster, D.L., J.A. Lemons, R.B. Jaffe, G.D. Niswender (1975) Sequential patterns of circulating leuteinizing hormone and follicle-stimulating hormone in female sheep form early postnatal life through the first estrous cycles. Endocrinology, 97:985.

Foster, D.L., I.H. Mickelson, K.D. Ryan, G.A. Coon, R.A. Drongowski, and J.A. Holt (1978) Ontogeny of pulsatile leteinizing hormone and testosterone secretion in male lambs. Endocrinology, 102:1137.

Guerne, J.M., and F. Stutinsky (1978) Estradiol and progesterone binding in rabbit placenta during gestation. Horm. Metab. Rs., 10:548-553.

Harbert, G.M., Jr., M.D. Harry, S. MeGaughey, Jr., D.A Scoggin, and W.N. Thorton (1964) Concentration of progesterone in newborn and maternal circulation at delivery. Obstet. Gynacol., 23:413-426.

Jensen, E.V., and E.R. DeSombre (1972) Mechanism of action of the female sex hormones. Annu. Rev. Biochem., 41:203-230. 
Kochhar, D.M. (1975) The use of in vitro procedures in teratology. Teratology, 11:273-288.

Landau, R.L., and K. Lugibihl (1961) The catabolic and natriuretic effect of progesterone in man. Recent Prog. Horm. Res., 17:249-292.

Levitz, M. (1966) Conjugation and transfer of fetal-placental steroid hormones. J. Clin. Endocrinol., 26:773-777.

Lowry, O.H., N.J. Rosegrough, A.L. Farr, and R.J. Randall (1951) Protein measurement with the Folin phenol reagent. J. Biol. Chem., 193:265-275.

Milo, G.E., W.B. Malarkey, J.E. Powell, J.R. Blakesle, and D.S., Yohn (1976) Effects of steroid hormones in fetal bovine serum on plating and eloning of human cells in vitro. In Vitro, 12(1):23-30.

New, D.A.T. (1967) Development of explanted rat embryos in circulating medium. J. Embryol. Exp. Morphol., 17:513-525.

New, D.A.T., and P.T. Coppola (1977) Development of a placental blood circulation in rat embryos in vitro. J. Embryol. Exp. Morphol., 37:227-235.

Niswender, G.D. (1973) Influence of the site of conjugation on the specificity of antibodies to progesterone. Steroids, 22:413.

O'Malley, B.W., and A.R. Means (1974) Female steroid hormones and target cell nuclei. Science, 183(4125):610620.

Prasad, A.S., E. DuMuchelle, D. Koniuch, and D. Oberlass (1972) A simple fluorometric method for the determination of RNA and DNA in tissues. J. Lab. Clin. Med., 80(4):598-602.

Ritter, E. (1978) RNA and DNA determination on 10 and 11 day rat embryos. Personal communication.

Solomon, S., and H.G. Friesen (1968) Endocrine relations between mother and fetus. Annu. Rev. Med., 19:399-430.

Vito, C.C., and T.O. Fox (1979) Embryonic rodent brain contains estrogen receptors. Science, 204(4392):517-519. 